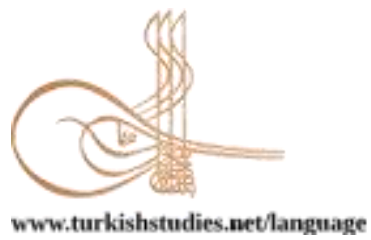

Turkish Studies - Language and Literature

eISSN: 2667-5641

Research Article / Araştırma Makalesi

\title{
Ekoeleştiri Kuramı Işığında Ayla Kutlu’nun "Huvava: İlk Çevre Koruyucu” Adlı Eserine Bakış*
}

\author{
An Insight into Ayla Kutlu's Work Entitled "Huvava: The First Environmental Protector" in the \\ Light of Ecocriticism Theory
}

Funda Bulut**

\begin{abstract}
The eco-criticism, which is rapidly gaining importance in our world, examines the natural balances that changed, transformed and deteriorated as a result of human activities. This theory, which investigates the relationship between literature and environment in the most general sense, aims to create eco-critical consciousness in an individual by addressing environmental problems from a perspective that does not separate man from nature. Eco-criticism, also known as environmental criticism; while trying to draw attention to many problems in the theoretical framework with different ecological approaches such as Abundance (Cornupoia), Environmentalism, Deep Ecology, Ecofeminism, Ecomarkism, Social Ecology and Heideggerian Ecophilosophy, it contributes greatly to the environmental consciousness. Eco-criticism, which gained a theoretical identity and became a discipline in the 1990s in the West, has also become one of the most important areas with increasing academic studies in our country, in recent years. As being a citizen of the world, the artists who carry environmental problems to fictional works, call in order to create awareness and environmental consciousness in the individual and live in harmony with the planet where they live by discussing ecological problems within the possibilities of the literature. Ayla Kutlu, one of these ecologically sensitive writers, wants to instill this environmental awareness in memories of the people responsible for the world they have been living in regardless of age, in her Huvava designated work. The author describes the struggle of Huvava, the protective spirit of the cedar forest, for the protection of nature, in her work which is a counter-epic from Gilgamesh. In the critical epic, which is a call text according to the author; Huvava lost his life as a result of his struggle with Gilgamesh and Enkidu and became the "first environmental protector". In this study where document analysis is used, the reasons of nature destruction will be brightened and how the perception of human with an egocentric perspective threatenes environment and future will be told by an ecocritical approach. When approached with ecological sensitivity, it will be seen that demonstration of wildlife as a threat by Gilgamesh epic, urban-nature conflict, the protection need of nature, and mentality that sees man apart from nature for the first time, was handled in the work.
\end{abstract}

\footnotetext{
* Bu çalışma, 2019'da Muğla Sıtkı Koçman Üniversitesi tarafından Bodrum'da düzenlenen Uluslararası Temel Eğitim Kongresi' nde (UTEK 2019) sunulan sözlü bildirinin genişletilmiş halidir.

** Dr. Öğr. Üyesi, Kastamonu Üniversitesi Eğitim Fakültesi Türkçe Eğitimi Anabilim Dalı.

Asst. Prof. Dr., Kastamonu University Faculty of Education Department of Turkish Education.

ORCID 0000-0002-7101-3496

fbulut@kastamonu.edu.tr

Cite as/ Atıf: Funda, B. (2020). Ekoeleştiri kuramı 1şığında Ayla Kutlu'nun "Huvava: İlk Çevre Koruyucu" adlı eserine bakış. Turkish Studies - Language, 15(2), 625-638. https://dx.doi.org/10.29228/TurkishStudies.41650

Received/Geliş: 06 February/Şubat 2020

Accepted/Kabul: 20 June/Haziran 2020

Checked by plagiarism software

Copyright $@$ INTAC LTD, Turkey

Published/Yayın: 27 June/Haziran 2020

CC BY-NC 4.0
} 
Structured Abstract: The eco-criticism, which is of increasing importance nowadays, investigates the natural balances that have changed, transformed and deteriorated in the world as a result of human activities. This theory, which investigates the relationship between literature and environment in the most general sense, aims to create eco-critical consciousness in the individual by addressing environmental problems from a perspective that does not separate human from nature. Eco-criticism, which gained a theoretical identity and became a discipline in the 1990s in the West, has also become one of the most important areas with increasing academic studies in our country, in recent years. Eco-critical analysis of novels, poems, stories and theatrical genres in Turkish literature raises the awareness of the individual about environmental problems and breaks the humancentered thinking structure and creates a serious literature formation in our country. As a result of the literature review, it was found that there is a lack of application of eco-criticism into children's literature. The aim of this study is to eliminate the gap in literature and to pioneer other studies in the works of children's literature and to contribute to the eco-critical studies whose importance is better understood with each passing day.

As being a citizen of the world, the artists who carry environmental problems to fictional works, call in order to create awareness and environmental consciousness in the individual and live in harmony with the planet where they live by discussing ecological problems within the possibilities of the literature. Ayla Kutlu, one of these ecologically sensitive writers, wants to instill this environmental awareness in memories of the people responsible for the world they have been living in regardless of age, in her Huvava designated work. The author describes the struggle of Huvava, the protective spirit of the cedar forest, for the protection of nature, in her work which is a counter-epic from Gilgamesh. In the critical epic, which is a call text according to the author; Huvava lost his life as a result of his struggle with Gilgamesh and Enkidu and became the "first environmental protector". In this study where document analysis is used, the reasons of nature destruction will be brightened and how the perception of human with an egocentric perspective threatenes environment and future will be told by an eco-critical approach. When approached with ecological sensitivity, it will be seen that demonstration of wildlife as a threat by Gilgamesh epic, urban-nature conflict, the protection need of nature, and mentality that sees man apart from nature for the first time, was handled in the work. Ayla Kutlu's adaptation of Gilgamesh epic, Huvava, aims to question human relations with nature while shedding light on environmental problems. The holistic view of deep ecology that does not differentiate between human and nature, which is proposed to establish a healthy and sustainable relationship with nature, is one of the basic messages Kutlu wants to give. While trying to show the damages caused by the human-centric perspective in her work, the author thinks about the basic responsibilities of the human being towards the environment and advocates a nature-centric ethical understanding. The mythical and animistic identity of this opposing epic, where Huvava lost his struggle with Gilgamesh and Enkidu, gained the title of "first protector of the environment" and turned into a hero of nature, constitutes a struggle to protect nature. Huvava, the protective spirit of a cedar forest, was tried to be killed by human beings. Meanwhile, not only trees are slaughtered and forests are destroyed, but also the animistic power of nature is ignored. In this epic, the author tries to create awareness by addressing the reasons underlying the emergence of this problem rather than addressing an environmental problem. Although the cutting of trees, the destruction of forests and the homelessness of living things in nature constitute the main subject of the epic, the author tries to leave a mark on the reader with the conflict of human-nature. While trying to emphasize the inaccuracy of man's attitude towards nature, she explains the cause of environmental problems with the perception of people trying to establish dominance over nature. Adapted from the epic of Gilgamesh, known as the story of a quest for immortality, Huvava comes from a common problem of concern to the world: the war of superiority between man and nature and the destruction of nature. Both epics are similar in terms of the message they want to give, although their writing and periods are different. Both of the works aim to raise environmental awareness in the reader by trying to draw attention to environmental problems, especially the forest massacre, the destruction of plant and animal species. As a matter of fact, in the preface of the epic Huvava, the author wrote, "I want to present my thoughts and feelings to humanity as a gift. Huvava's story, which I submit to all conscious people ignoring their age, is the text of the call that I wrote as a counter-epic. I want the memory of young generations to shine like the fireflies that illuminate the values of the earth" (Kutlu, 2009: 8). Throughout the epic, the author tries to create a symbolic environmental hero and tries to create an environmental awareness in the reader with the messages he tries to give through him, and tries to leave a permanent mark with the power of art and aesthetic language.

In her work, Kutlu gave the message that the central problems of human beings underlie his environmental problems. She pointed out that the mentality, which sees man as the master of nature and tries to put nature under the control of human beings, is not only the problem of today and underlined that the

Turkish Studies - Language, 15(2) 
painting in the present is not different as it was in thousands of years ago. Kutlu, who tries to emphasize the inaccuracy of man's attitude towards nature in Huvawa, aims to replace the eccentric view of human perception, which is one of the fundamental goals of deep ecology. It is possible to see the reflections of inherent value, biospheric wealth and diversity, which form the basis of deep ecology philosophy in nature-centric ethics. In the epic, in which the message that each being in the ecosystem is special and valuable in itself, ignoring the animistic power of nature and the destruction of nature with the desire to establish civilization, has been criticized. When the work is approached with ecological sensitivity, it is seen that many ecological issues such as the legend of Gilgamesh adapted from wildlife as a threat to wildlife, the need for protection of nature, and the mentality of seeing man apart from nature for the first time, was handled in the work. Addressing all ears who can hear the sound of nature with the story of Huvava, the author tells the invincibility of the right, the side of peace, the greatness of forgiveness, the power of courage and the greatness of love. Huvava, who teaches to love nature more than defending it, becomes the symbolic environmental hero for both children and adults while carrying the title of being the first environmental protector to immortality. The author is stating that the first environmental protector must be removed from the dusty pages of history and his struggling spirit should be an example to humanity (Kutlu, 2009: 7)

Keywords: environment, literature, eco-criticism, Huvava, Epic of Gilgamesh, Ayla Kutlu

Öz: Dünyamızda önemi hızla artmakta olan ekoeleştiri, çoğunlukla insan faaliyetleri sonucunda dünya üzerinde değişen, dönüşen ve bozulan doğal dengeleri inceler. En genel anlamda edebiyatla çevre arasındaki ilişkiyi inceleyen bu kuram, insanı doğadan ayrı tutmayan bir bakış açısıyla çevresel sorunları ele alarak bireyde ekoeleştirel bilinç oluşturmayı hedeflemektedir. Çevreci eleştiri olarak da bilinen ekoeleştiri; "Bolluk (Cornupoia), Çevrecilik, Derin Ekoloji, Ekofeminizm, Ekomarksizm, Toplumsal Ekoloji ve Heideggerci Ekofelsefe"... gibi farklı ekolojik yaklaşımlarla birçok soruna kuramsal çerçevede dikkat çekmeye çalışırken çevreci bilince büyük katkıda bulunur. Batı'da 1990'lardan sonra kuramsal bir kimlik kazanarak bir disipline dönüşen ekoeleştiri, son yıllarda ülkemizde de günden güne artan akademik çalışmaların önemli alanlarından biri haline gelmiştir. Bir dünya vatandaşı olarak çevresel sorunları kurmaca eserlere taşıyan sanatçılar, edebiyatın imkânları dahilinde ekolojik problemleri tartışarak hem bireyde farkındalık ve çevresel bilinç oluşturmaya hem de yaşadıkları gezegenle uyum ve ahenk içinde yaşamaya çağrıda bulunmaktadırlar. Bu ekolojik hassasiyete sahip yazarlardan biri olan Ayla Kutlu, "Huvava" adlı eserinde yaş gözetmeksizin içinde yaşadığı dünyaya karşı sorumlu olan belleklere bu çevre bilincini aşılamak ister. Yazar, Gılgamış’tan uyarladığı "bir karşı destan” niteliği taşıyan eserde sedir ormanının koruyucu ruhu Huvava'nın doğayı koruma mücadelesini anlatır. Yazarın deyimiyle bir “çağrı metni” özelliği gösteren eleştirel destanda Huvava, Gılgamış ve Enkidu ile girdiği mücadele sonucunda hayatını kaybederek "ilk çevre koruyucusu” unvanını kazanır. Doküman analizinin kullanıldığı bu çalışmada doğa tahribatının nedenlerine 1şık tutulurken benmerkezli bir bakış açısına sahip insan algısının insan, çevre, gelecek için oluşturduğu tehdit ekoeleştirel bir yaklaşımla anlatılacaktır. Ekolojik duyarlılıkla yaklaşıldığında eserde Gılgamış destanının yaban hayatı tehdit olarak göstermesi, kent-doğa çatışması, doğanın korunmaya ihtiyaç duyar hale gelmesi ve insanı ilk kez doğadan ayrı gören zihniyet gibi birçok çevresel sorunun ele alındığı görülecektir.

Anahtar Kelimeler: çevre, edebiyat, ekoeleştiri, Huvava, Gılgamış Destanı, Ayla Kutlu.

\section{Giriş}

Çevre sorunlarına duyarsız kalmayan edebiyatın bir uzantısı olan ekoeleştirinin en bilinen tanımlarından biri, Cheryll Glotfelty'e aittir. Yazarın 1996 yılında yayımladığı "Literary Studies in Age of Environmental Crisis" [Çevre Krizi Çağında Edebiyat Çalışmaları] eserinde ekoeleştiri, "edebiyat ve fiziksel çevre arasındaki ilişkinin incelenmesi" (Oppermann, 2012: 9) şeklinde tanımlanır. Daha geniş tanımıyla ekoeleştiri, "insanla insandışı arasındaki ilişkinin insanlı̆̆ın kültürel tarihi boyunca incelenmesi ve bizzat 'insan' kavramının eleştirel bir incelemesidir" (Garrard, 2017: 17). Ekosistemin bir parçası olduğunu unutarak tüm doğal kaynakları kontrolsüzce kullanıp canlılara zarar veren insanoğlunun kapitalizmin kaçınılmaz sonu tüketici kültürün etkisiyle dünyaya ve doğaya bakışı daha da acımasız bir hale gelmiştir. Ekolojik düzene saldırarak çevresel felaketlere kulak tıkayan bu sömürü zihniyeti, aynı zamanda bunu kendinde bir hak olarak görmüştür. 
İnsanın kendinden başka canlı ve cansız varlıklara yaşam hakkı tanımayan bu düşüncenin altında yatan sebeplerden biri madde-söylem ikilemi gizlidir. "Akıl ve madde ayrımı yapan dualistik düşünce biçiminde akıl sahibi olan tek varlı olarak sınıflandırılan insanlar, kendilerini diğer maddesel varlıklardan ayrı bir yere koymuşlardır. İnsanların akıl sahibi olmadıklarını düşündükleri, bu yüzden de kendilerinden daha değersiz olarak nitelendirdikleri diğer canlılar üzerinde söz sahibi olduğunu savunan söz konusu felsefe, insanların bakış açısına yön ver"miştir (Yılmaz, 2012: 130). Aklın üstünlügünü savunan Batı felsefesi, yanında tek Tanrılı dinlerin bazı ögretileri de doğayı insanın hizmetine sunulmuş bir varlık gibi göstererek insana doğaya hükmedebileceği düşüncesini aşılamıştır. Bu insanı doğadan ayrı ve özel tutan bakış, insana kendisinden başka bir canlı olduğunu ve doğayla iletişim halinde olduğunu zamanla unutturarak çevre sorunlarına neden olmuştur. Derin ekolojinin kurucularından Arne Naess'in da vurguladığı gibi insanı doğadan üstün gören anlayışın kaynaklarından bazıları da tek Tanrılı dinler ve Batı felsefesidir. İnsan ve doğa arasındaki ilişkiyi basite indirgeyen "sığ ekoloji” başta olmak üzere yüzeysel çevre anlayışlarının çevresel sorunların çözümünde yetersiz olduğunu iddia eden Naess, insan-merkezli bakış açılarını eleştirir. Çünkü "Süregelen insan merkezli, bakış açısıyla sı̆̆ ekoloji, insan ve doğa arasında çıkarcı bir ilişki kurar. İnsanın doğa içerisinde onun hakimi ya da efendisi rolünü üstlenerek sinırsı sömürü potansiyeline sahip bir tür olarak algilanmast ve bunun sonucunda doğay istediği gibi kullanmast siğ ekolojinin temel yapı taşları arasındadır. (...) ve de Naess' in da belirttiği gibi günümüz çevre sorunları hep bu geleneksel /insan doğa ayrımından kaynaklanmaktadır"(Dindar, 2017: 60). Çevresel sorunların kaynağında insanın olduğuna dikkat çeken derin eleştirinin temel hedeflerinden biri de bu insan merkezci algıyı yıkarak yerine doğa merkezci (eco- centric) bir bakış açısı getirebilmektir.

Derin ekoloji felsefesinde insanın doğa ile ilişkilerini ve doğa algısını yeniden sorgulaması gerektiğine inanan Naess'in yaklaşımının kaynağında da Budizm, Taoizm, Şamanlık gibi Doğu kaynaklı dinler, mitler yer alır. Bir başka deyişle "Derin ekoloji aynı zamanda Batı kaynaklı olmayan görüşlere de büyük bir saygı gösterir. Süreç içindeki birlik ve dünyanın para-psikolojik olarak kavranışı Doğu'nun spritüel geleneklerinde ve Batıl olmayan diğer insanların mitolojik sistemlerinde gelişstirilmiştir. Derin ekolojinin gü̧̧ peşinde olmayan duyarlılı̆̆ı ile örtüş̧ügüüden, tüm bu geleneklerin bazılarında var olan dünyada-var-olma şekli ya da duyarlıllğı da aynı şekilde saygıyla karşılanır (Dindar, 2012: 66). Derin ekolojinin doğayı anlamlandırırken beslendiği felsefi, dini ve mistik akımların ortak özelliği, insanı-doğadan ayrı ve üstün tutmayan bakış açısıdır. Bunun en dikkat çekici örneğini dünyadaki her varlığın bir ruhu olduğuna ve bu varlıkların da çevreleri ile iletişim içinde olduğuna inanılan animizmde görmek mümkündür. Animizm (canlıcılık) adıverilen bu inanca göre "dünyada yaşayan her canlının bir ruhu vardır, insanın kendi çevresindeki ilişkileri, insanın diğer bir insanla olan ilişkileri gibidir, taş ya da nehir, ağaç hep canlı bir ruha sahiptir ve bu varlık ile ruh arasındaki ilişki süreklidir"(Güller, 1995: 159). Bu da ruh sahibi olduğuna inanılan doğaya ve doğadaki her varlığa saygı göstermeyi ve onlarla uyum içinde yaşamayı zorunlu kılmaktadır. Bu düşünce sistemine göre doğaya bağımlı olan insan da doğal kaynakları ihtiyaçları doğrultusunda kullanarak ekolojik dengeyi korur ve doğayla sürekli iletişim halinde olduğu aynı zamanda ona sayg1 duyduğu için zarar verecek bir davranışta bulunmayı bile düşünmez. Ekoeleştiride de uzun süre tartışılan ve farklı görüşlere açık olan animizm konusunu ele alan ekoeleştirmenlerden Lynn White, "Historical Roots of Our Ecological Crisis" adlı makalesinde bu konuya şöyle değinir: “... her ağacın, her pınarın, her tepenin bir koruyucu ruhu vardır ve bir ağacı kesmeden, bir dağı kazmadan ya da bir nehrin önüne set çekmeden önce ruhları yatıştırmak gereklidir, bu doğanın animistik gücüdür" [(Sümer, 2016: 744- 745) White, 1996: 10]. Ekosistemde eşit haklara sahip olan varlıklar, doğa merkezci bir anlayışın etkisiyle koruma altındadırlar. Çünkü animistik güç, kutsalın dokunulmazlığı sayesinde insan davranışlarının kontrol ederek doğal tahribatı önler. Ülkemizde ve dünyamızda önemi hızla artmakta olan ekoeleştiri (çevreci eleştiri); çoğunlukla insan faaliyetleri sonucunda dünya üzerinde değişen, dönüşen ve bozulan doğal dengeleri inceler. "Bolluk (Cornupoia), Çevrecilik, Derin Ekoloji, Ekofeminizm, Ekomarksizm, Toplumsal Ekoloji ve Heideggerci Ekofelsefe"... gibi farklı ekolojik yaklaşımlarla, birçok soruna kuramsal bir çerçevede 
dikkat çekmeye çalışan ekoeleştiri, insanı doğadan ayrı tutmayan bir bakış açısıyla çevresel sorunları ele alarak bireyde ekoeleştirel bilinç oluşturmayı hedeflemektedir. Türk edebiyatında roman, şiir, hikaye ve tiyatro türlerinde yapılan ekoeleştirel incelemeler, bireyi çevre sorunları konusunda bilinçlendirerek insan merkezli düşünce yapısını kırılmasına ve ülkemizde ciddi bir literatür oluşumuna zemin hazırlamaktadır. ${ }^{1}$ Yapılan literatür taraması sonucunda ekoeleştirinin çocuk edebiyatı eserlerine uygulanması noktasında eksiklikler olduğu tespit edilmiştir. Bu çalışmada alanyazınındaki boşluk giderilerek çocuk edebiyatı eserlerinde yapılacak diğer çalışmalara öncülük etmek ve önemi her geçen gün daha da iyi anlaşılan ekoeleştirel incelemelere katk1 sağlamak amaçlanmaktadır.

Ayla Kutlu'nun Gılgamış destanından uyarladığı Huvava adlı eseri, çevre sorunlarına ışık tutarken insanoğlunun doğa ile ilişkilerini sorgulatmayı hedefler. Derin ekolojinin doğa ile sağlıklı ve sürdürülebilir bir ilişki kurmak için önerdiği insan-doğa ayrımı yapmayan bütünsel bakış açısı, Kutlu'nun da vermek istediği temel mesajlardan biridir. Eserinde insan-merkezci bakış açısının verdiği zararları göstermeye çalışırken insanın çevreye karşı temel sorumlulukları üzerine düşündüren yazar, doğa-merkezci bir etik anlayışı savunur. Huvava'nın Gılgamış ve Enkidu ile girdiği mücadeleyi kaybetmesi, "ilk çevre koruyucusu" unvanı kazanması ve bir doğa kahramanına dönüşmesinin anlatıldığı bu karşıt destanın çekirdek hikâyesini mitik ve animistik bir kimliğin doğayı koruma mücadelesi oluşturur. Bir sedir ormanın koruyucu ruhu olan Huvava, insanoğlu tarafından öldürülmeye çalışılırken sadece ağaçlar ve orman katledilmemekte doğanın animistik gücü de görmezden gelinmektedir. Söz konusu destanda yazar, bir çevre sorununa değinip geçmektense bu sorunun ortaya çıkışının altında yatan nedenlere de eğilerek farkındalık yaratmaya çalışır. Ağaçların kesilmesi, ormanların yok edilmesi ve doğadaki canlıların evsiz bırakılması destanın temel konusunu oluştursa da yazar, insan-doğa çatışması ile okurda bir iz bırakmaya çalışır. İnsanın doğa karşısındaki tavrının yanlışlığını vurgulamaya çalışırken çevre sorunlarının nedenini de doğa üzerinde hâkimiyet kurmaya çalışan insan algısıyla açıklar.

\section{1. İnsanla Doğa Arasındaki İlk Duvarın İnşası: Ekosistemin Tehdidi}

Çevresel sorunlara duyarsız kalmayan Ayla Kutlu, Gılgamış destanının², önemli kahramanlarından biri olan Huvava'yı hem eserinin merkezine hem de adına taşıyarak kendi karşıt

\footnotetext{
${ }^{1}$ Ekoeleştirinin Türkiye'de tanınmasına olanak sağlayan önemli çalışmaların başında Serpil Oppermann'ın önderliğinde hazırlanan "Ekoeleştiri Çevre ve Edebiyat" adlı kitap gelir. Ekoleştiriyi tanımlayarak kuramın doğuşu ve gelişimi hakkında bilgiler verilen çalışmada farklı ekoeleştirel yaklaşımlar tanıtılarak Türk edebiyatından seçilen eserler üzerinde uygulamalar yapılmıştır. Türler arasında oldukça rağbet gören romanla ilgili ekeoleştirel incelemelerden biri, Çiğdem Arlı Cengiz'e aittir. Kadın ve doğaya aynı pencereden bakan ekofeminizmi tanıtan çalışma, Buket Uzuner'in "Uyumsuz Defne Kaman'ın Maceraları Su Romanına Ekoeleştiri ve Ekofeminizm Penceresinden Bakış” adını taşır. Aynı türdeki diğer çalışmalar, Macit Balık'ın “Çevreci Eleştiri Iş̧ı̆ında Latife Tekin'in Romanları”, Macit Balık ve Bilgen Tekben'in ,"Çevreci Eleştiri Kuramı Açısından Müge İplikçi’nin Cemre Adlı Romanı”, Cem Yılmaz Budan'ın "Çevreci Eleştiri Bağlamında Yaşar Kemal'in Kuşlar da Gitti Romanı Üzerine Bir Değerlendirme”sidir. Melis Ergin ve Özen Nergis Dolcerocca'nın "Edebiyata Ekoeleştirel Yaklaşımlar: Ekoşiir ve Elif Sofya" adlı makalesi, ekoeleştirel şiir incelemelerine öncülük etmesi açısından önemlidir. Şiir alanında dikkat çeken çalışmalar arasında Hakan Sazyek ve Yunus Sürücü'nün "Cahit Külebi’nin Şiirlerine Ekoeleştiri Çerçevesinden Bakmak", Mihrican Aylanç'ın "Fikret Demirağ’ın Şiirlerine Ekoeleştirel Bakış" da yer alır. Hikâye türünde biri Betül Bayraktar'a ait "Birey-Doğa İlişkisi Temelinde Kendisi Olamama: Mustafa Kutlu Öykülerini Eleştirel Okumak" diğeri de Meral Avuklu'ya ait "Sabahattin Ali'nin Bir Orman Hikâyesi Adlı Hikâyesine Ekoeleştirel Bir Bakış" başlıklı iki inceleme bulunmaktadır. Tiyatro türünde ise Caner Solak'ın kaleme aldığı "Bir Ekoeleştiri Denemesi: Behiç Ak’ın Tek Kişilik Şehir Oyununda Birey, Toplum ve Çevre İlişkileri” adlı makalesi, bu alanın ilk örneklerindendir. Ayrıca Celal Aslan'ın Memet Baydur'un "Tensing Adlı Tiyatro Oyununa Ekoeleştirel Bir Yaklaşım" adlı eseri de dikkate değerdir. Bunlara ek olarak Turgay Kabak'ın "Dadaloğlu'nun Şiirlerine Ekoeleştirel Bir Yaklaşım" başlıklı makalesi de ekoeleştirinin Yeni Türk edebiyatı alanından sonra Halk edebiyatında da ilgi görmeye başladığının bir göstergesidir. Çocuk yazının da ise Sıddıka Dilek Yalçın Çelik'in "Aytül Akal'ın Orman Masalları Kitap Dizisi Örnekleminde Çocuklara Çevreci Bakış Açısının Verilmesi”" ile Betül Mutlu ve Nuran Başoğlu'nun "Ekoeleştiri Kuramına Göre Aytül Akal'ın Ağaç Masalları'nda İnsan-Doğa İlişkisi”' isimli bildirileri, ilk akla gelen çalışmalardır.

${ }^{2}$ Ayla Kutlu, Huvava eserinden önce 1994'te yayınladığ Kadın Destanı adlı eserinde de Gılgamış destanını yeniden yorumlar. Eserde bir tapınak fahişesinin gözünden Gılgamış'ın ölümsüzlük arayışını ve kadın olmanın öyküsünü anlatan
} 
destanını oluşturur. Bir çevre destanı niteliği taşıyan eser, tarihin eski anlatılarından Gılgamış Destanı'nın mitolojik kahramanlarını günümüze taşımasının ötesinde beş bin yıl önceki çevre koruyucusunun simgesel kahramanını okura tanıtması açısından önemlidir. Eserin önsözünde Huvava'yla nasıl tanıştığını anlatan Ayla Kutlu, Gılgamış destanının kendi üzerindeki etkisini ve zamanla iç dünyasında şekillenen Huvava imajını şöyle anlatır:

\begin{abstract}
“ilkokuldayken Sumer'lerin Gilgameş adındaki en büyük kralının bir serüvenini okudum. Gilgameş Destanından bir bölümdü bu. (...) Huvava'nın bir vahşi, bir canavar, bir düşman olduğuna on yaşımı sürdürdüğ̈̈m o günlerde bile tam inanmamıştım. Zamanla her insan gibi şunu öğrendim: Bize bir olayı mutlak gerçek olarak binlerce kez anlatsalar da anlatılanlar doğru ve haklı olmayabilir. Altmış yıldan beri aklımdan çıkmayan gerçek şudur: Huvava haksızca suçlanıyordu. O doğayı koruyordu” (Kutlu, 2009: 6).
\end{abstract}

Çocukluğunda tanıştı̆̆ bir destan kahramanını çevresel bilinçle yeniden kaleme alan yazar, Gılgamış Destanına farklı bir dikkat ve Huvava'ya da yeni bir bakış kazandırır. "İlk Çevre Koruyucusu", "Huvava'nın Hikâyesi", "Yenilgi" ve "Yeniden Doğuş" olmak üzere dört bölümden oluşan eserin ilk bölümünde kitaba ismini veren Huvava kısaca şöyle tasvir edilir: "Ormanın koynunda büyüdü/ Onu gözledikçe yeşile kesti/ Bakışlarında o yüzden ormanlar gölgelenir/ Çam soluyup mavi gökleri içer güçlenir,/ Elleri ir dallar gibi sürgit büyür/ Tomurlanır çoğalır her ilkbahar/ Kalın parmakları hapseder kötü ne varsa/ Ağaç kökleri gibi derin topraklara dalar" (Kutlu, 2009: 9). Kökü toprak, vatanı ve yuvası orman, gövdesi yeşil, soluğu çam, içkisi mavi gök olan Huvava'nın annesi süreğen doğuş ve babası da doğanın gücüdür. İlkbahar mevsiminde tüm ağaç ve bitkiler gibi yeniden doğuşa eşlik eden, kötülükleri uzaklaştıran kahramanın gizli hazinesi de varoluş sebebi de doğadır. Bu tasvire göre ormanın koynunda büyüyen Huvava'nın onun ayrılmaz bir parçası olduğu görülür. Destanın ilerleyen bölümünde varoluşu hakkında fazla bilgiye sahip olunmadığını belirten yazar, kahramanın adının anlamının da bu adı ona kimin verdiğinin de bilinmediğini söyler. Kaynaklarda geçen Huvava'nın diğer adı Humbabadır ve Mezopotamya mitolojisi sözlüğüne göre "Gılgamış destanında adı geçen bir sedir ormanının koruyucu ruhu olup Gılgamış ve Enkidu tarafından öldürülmüştür” (Öztürk, 2020). Eserde de vurgulandığı gibi “Kimdir kimin nesidir bilmez" isek de bilinen ilk çevre koruyucusudur.

Destanın ikinci bölümünü oluşturan “Huvava'nın Hikâyesi”nde Huvava'nın evi, yurdu, ailesi, kökleri kısaca yaşam kaynağı doğa anlatılır. Lübnan ve Amanos dağlarının güzelliği, ormanın önemi, sedir ağaçlarının ölümsüzlüğü Huvava'nın gözünden aktarılırken onun doğa sevgisine vurgu yapılır. Dağları, ormanları ve ağaçları övgü dolu sözlerle tasvir ederken onlara duyduğu hayranlığı benzetmelerle güçlendiren Huvava, iyelik ekleriyle de sahiplenme duygusunu pekiştirir. Dağların bir dizi gövermiş inciye, rrmakların aynaya, ormanların anaya, bitki örtüsünün yeşil bir kürke benzetildiği destanda her şey birbiriyle etkileşim halindedir ve yaşam ağına katkıda bulunmaktadır. Ormanların katledilişini konu alan destan, bireye ağaçların ekolojik dengenin devamlılığındaki yeri ve önemini sorgulatırken tarihi süreçte ona yüklenen anlamlar üzerine de düşündürür. Yazar tarafından kutsal olarak adlandırılan sedir ağaçları, yaşamdan koparıldığı halde yaşayabildiği için ölümsüz olarak nitelendirilmektedir.

Şiirde güneyden kuzeye doğru uzanarak yaşının coğrafyadan büyük olduğu belirtilen dağlar, dik başlarıyla güçlü bir sınır oluştururken orman, zenginlikleriyle doğadaki tüm canlıları; Akdeniz,

\footnotetext{
yazar, kadına yönelik şiddetin ataerkil düzenle bağlantısıyla birlikte insan-doğa-kültür ilişkilerini inceler. Daha fazla bilgi için bakılabilir: Özlem, Uzundemir (2005). "Ayla Kutlu's Kadın Destanı and the Modification of the Epic", Ankara Üniversitesi Fen-Edebiyat Fakültesi, Journal of Arts and Sciences 1 (3): 119-126; Nilsen, Gökçen (2011). "Kadın Destanı: Kadın-Doğadan Erkek-Uygarlığa Bir Başkaldırı Anlatısı”, Kadın Yazarlar Sempozyumu Bildiriler Kitabı: Ayla Kutlu Edebiyatı, İstanbul, 275-287; G. Gonca-Gökalp-Alpaslan (2007). Metinlerarası İlişkiler ve Gılgamış Destanının Çağdaş Yorumları, İstanbul: Multilingual Yayınları.
} 
buğusuyla havasıyla kutsal sedir ağaçlarını, dağlardan ovalara yayılan ırmaklar da birçok bitkiyi besleyip canlandırıp yaşatmaya devam eder. Kutlu'nun vurguladığı gibi yeryüzünde birbirine farklı şekillerde bağlı olan varlıkların her biri, kendi içinde ayrı bir değere sahiptir ve bu dizelerde Naess'in derin ekoloji felsefesinin temelini oluşturan içsel değer (intrinsic value) [ya da bir başka deyişle doğasında bulunan değer (inherent value)], biyosferik zenginlik ve çeşitlilik kavramlarının yansımalarını görmek mümkündür. Akdeniz'i özel kılan canlı varlıkların özelliklerini anlatan dizelerin sonunda yaşamın devamlılığına dikkat çekilirken doğanın sonsuz bir yaşam döngüsüne sahip olduğunun altı çizilir. Doğada kendi varoluşundan bağımsız olarak bir akış olduğunu hatırlatan Huvava, kendi hikâyesini anlattığı şiirinin ilk dizelerinde bu akışı bozmak isteyenlerin varlığından söz eder. Çok sevdiği dağlarının birçok düşmanı olduğunu açıkça söyleyerek ekosistemin tehdit altında olduğunu sezdiren destan kahramanı, "Ben görmesem de... Ben dağın güvenci: Huvava" (Kutlu, 2009: 13) sözleriyle hem koruyucu kimliğine hem de insanla doğa arasında inşa edilen ilk duvara gönderme yapar.

\section{Erk'in Gücünü Kötüye Kullanması: Doğaya Zulüm}

Eserin ikinci bölümünü oluşturan Huvava'nın hikâyesi, aynı zamanda Gılgamış'ın hikâyesidir ve destan doğaya savaş açan Gılgamış'ın hikâyesinin anlatmaktan öte bizzat 'insan' kavramının eleştirel bir incelemesidir. Aç gözlülüğü, hırsı ve acımasızlığı ile bilinen Gılgamış, kaynağını gücünden alan zalim biri olarak tasvir edilir. Doğunun yüreklere korku salan kralı, destanda da belirtildiği gibi "Tanrının rahat nedir bilmesin diye cezalandırdığı" (Kutlu, 2009: 4) biridir. Görünüşte kazandığ 1 zaferler ve kurduğu ihtişamlı kentlerle güçlü bir hükümdar portresi çizen Gılgamış, kentlerin çevresine diktiği duvarlarla ülkesini düşmanlardan korumaya çalışır. Herkesi düşman olarak gören ve halkını surlar arkasında koruyabileceğini düşünen hükümdarın kendisine ve ülkesine herhangi bir tehdit ya da bilinen bir saldırı söz konusu değildir. Eserde de bir düşman yokken kentlerin korunmaya ihtiyaç duyulmasını eleştiren yazar, Gılgamış'ın sedir dağı ormanına saldırması için geçerli bir nedeni olmadığını tam tersine doğanın ondan korunması gerektiğini şu dizelerle anlatır:

“Kentlerinin çevresine yedinci kez duvar dikecekler

Düşmandan korunacaklardı güya

Gllgameş bir zulümdü

Oydu bütün kentlerin düşmanı

Ölüm ekip ölüm biçiyordu hiç bıkmadan

Doymuyordu hiçbir yengiye

Koruyacağını söylüyordu insanlarını yedi kat surun ardında

Saldırlyordu her zaman biraz daha canavarlaşarak" (Kutlu, 2009: 15)

Huvava'da Gılgamış'ın setler çekerek kenti doğadan ayırmasının anlamsızlığına dikkat çekilirken bunun nedenleri üzerinde fazlaca durulmamıştır. Yalnız Gılgamış destanı üzerinde yapılan incelemeler, konuya daha derinlikli cevaplar getirecektir. Örneğin Sarıkaya'nın Gılgamış destanı üzerinde yaptığı ekolojik çözümlemede Gılgamış'ın doğaya saldırma nedeni ve Uruk kentinin dışardan bir saldırı olmadığı halde korunma çabası, doğa üzerinde hakimiyet kurmaya çalışan insanmerkezci bakışa bağlanır. Ün ve şöhret kazanarak ölümsüzlüğe kavuşmak isteyen Gılgamış'ın kendi ülkesini doğal dünyadan soyutlama isteği de doğa ve doğadaki canlılarla iletişime geçmekten duyulan rahatsızlıkla açıklanır. İddiaya göre bunun kaynağında ise "insanın kendisini besleyen ve varlığını borçlu olduğu ekosisteme ne kadar bağlı olduğunu bilmemesi ve bu nedenle de ekosisteme başkaldırarak ona hükmetmeye çalışma içgüdüsü(...) ile doğal afetlere karşı savunmasız durumda olan insanların bir tür savunma mekanizması geliştirmesi” (Sarıkaya, 2012: 104-105) yer alır. 
Gılgamış destanından uyarlanan Huvava adlı eserde de doğadan güçlü olduğunu doğa üzerinde kurduğu hâkimiyetle göstermeye çalışan Gılgamış, ekosistemin bir parçası olduğunu unutan, hırslarına yenik düşmüş insanın temsili bir örneğidir. "Güce doymayan güçlü kral”, "doymuyordu hiçbir yengiye", "saldırıyordu her zaman biraz daha canavarlaşarak" dizeleri, bireyin aç gözlülüğü, hırsları ve doyumsuzluğu yanında erkin artan gücü karşısında kontrol edemediği doyumsuz egosunu ve bu gücün altında ezilişini de anlatır. Destanda sedir ağaçlarını yok etmek için gelen Gılgamış resmedilirken kullanılan "Ah, gelenler güçlüydüler/ Çoktular, gözlerini düşmanlık bürümüştü” ve "Gılgameş bir zulümdü" ifadeleri de erkin bu gücünü kötüye kullandığının bir göstergesidir. Bu tasvirlere göre Gılgamış, bencil, duyarsız ve acımasız bir doğa düşmanıdır ve ilerleyen dizelerde G1lgameşler her devirde yaşar/ Kan ve acıyla kirletirler dünyayı" (Kutlu, 2009: 16) sözleriyle vurgulandığı gibi gücünü kötüye kullanan hükümdarlar her devirde var olmuş, hem kendi halkına hem de doğaya zulmetmişlerdir. Destanda da dikkat çekildiği gibi bazen bir tahta ya da unvana sahip olmasa da erki elinde bulunduran insanoğlu kendi özel meseleleri, çıkarları ve gücü için doğayı feda etmekten çekinmemiş ve doğanın içsel değerini görmezden gelmiştir. Huvava'daki doğayı yok etme arzusuna ekoeleştiri çerçevesinden bakıldığında sorunun insanın doğa ile kurduğu ilişkide olduğu bunun merkezinde ise insanın doğaya bakış açısında gizli olduğu görülür.

Gılgamış destanını Huvava'yı eksene alarak yeniden yorumlayan Kutlu, eserinde Gılgamış'ın doğayı yok etme arzusu yanında doğaya yaptığı zulmü ayrıntılı olarak işler. Ormandaki birçok varlığın kişileştirilerek ayrıntılı tasvir edilmesi, doğaya zulmün boyutlarını ortaya koyarken esere de bir çevre destanı kimliği kazandırır. Huvava'nın gözünden anlatılan sedir ormanının katlediliş hikâyesi, bir trajedi havasındadır.

"Sedirleri kesmeye gelenler;

Baltalarını, o korkunç silahlarını

Kaldırıp indirmeye başladıklarında

A ğaçların ne çok yuva biriktirdiklerini düşünmediler

Hiçbir önemi yoktu yorgun göçmen kuşların

A ̆gaçkakanların ve sincapların

Uzun kuyruğu ăgaç bedenlerini okşayan tilkilerin,

Kurnaz yüzlerin, saf bakışların, yeraltında

Korkuyla bekleyenlerin" (Kutlu, 2009: 16)

Sedir ağaçlarının kesilişi sırasında ormanda yaşayan varlıkların bundan nasıl etkilendiğinin uzun uzun anlatılması, okurun onlarla duygusal özdeşim kurmasını sağlarken okurda doğanın kendi içinde gizli bir hiyerarşiye sahip olduğu fikrini de güçlendirir. Gılgamış'ın sedir ağaçlarını keserek ormanın doğal dengesini bozması, ekoeleştirinin temel prensiplerinden her şeyin birbirine bağlılığı ilkesiyle ilişkilendirilebilir. Naess'in "Ecosophy and Gestatlt Onthology"[Ekofelsefesi ve Gestatl Ontolojisi] (1995) isimli makalesindeki deyimiyle (...) içinde yaşadığımız ekosisteme verdiğimiz bir zarar, sistemin tümüne, dolayısıyla da kendimize verdiğimiz bir zarardır” (Sarıkaya, 2012: 117-118). Huvava'da doğaya verilen zararın sadece sedir ağaçlarının kesilmesi olmadığı ağaçlarla birlikte ormanın tahrip edildiği, birçok bitki ve hayvan türünün yok olduğu, atmosferdeki oksijen dengesinin bozulduğu ve en önemlisi de insanın yeşilden uzak kalarak yine en büyük zararı kendisine verdiği mesajı verilir. Ayrıca okur yeraltında ve yerüstünde doğadaki herhangi bir varlığa verilen zararın doğurduğu çevresel felaketin sonuçları üzerine düşündürülürken onun ekosistemdeki mükemmel uyum ve ahengi yeniden keşfetmesi sağlanır.

Huvava'nın Gılgamış'la giriştiği savaşta sedir ormanını düşmana karşı savunan doğa koruyucusunun gözünden doğadaki zenginlik uzun uzun aktarılır. Gılgamış’1 ve ordusunu yenmek 
için firtına çıkaran Huvava, Amanosların kırığından uzanarak Akdeniz üzerinde dolaşırken doğadaki yaşam ağının kendi içindeki mükemmel uyumunu farklı benzetmeler ve uzun sıfat tamlamalarıyla çarpıcı bir şekilde gözler önüne serer:

"Ve kıyıdaki yengeçlerin, denizyıldızlarının, kestanelerin;

Siçanların ve onların ardındaki kedilerin...

Durduğunda dağdan büyük görünen dă̆ arslanlarının

Küçük birer serseri olarak yaşayıp ölen

Oğul ballarını miras birakan balarılarının"...(Kutlu, 2009: 22)

Huvava'nın uzun bir liste tutacak bu detaylı anlatımında ağaçkakan, sincap, tilki gibi ormanın dermirbaşlarından balık, sardunya, yengeç gibi deniz hayvanlarına saat çiçekleri, gülhatmiler, kapari gibi farklı türdeki bitkilerden bulut, yıldız, gece ve güneşe kadar oldukça geniş bir yelpazede birçok varlığa yer verilir. Yazarın da vurgulamak istediği gibi Huvava'da korunmak istenen sadece ağaçlar değil ağaçların da içinde yer aldığı birbirine bağlılığı ile ön plana çıkan doğadır. Ekosistem içinde her bir varlığın kendi içinde özel ve değerli olduğu mesajı verilen destanda dikkat çeken bir diğer nokta da derin ekoloji öğretisinin önemli ilkelerinden biri olan biyolojik çeşitliliğe ve zenginliğe vurgu yapılmasıdır

Destanın en uzun bölümüne karşılık gelen ikinci bölümde zalim Gılgamış’ın doğaya zulmü etkileyici bir dille gözler önüne serilirken doğanın da kendini korumak için direniş içinde olduğu belirtilir. Bu bölümde ormana ölüm getirenin karşısına nefesiyle çıkan Huvava, çıkardığı fırtınayla Gılgamış ve arkadaşı Enkidu'yu şaşırtarak durdurmayı başarır. Rüzgarla düşmanının yollarını kesen, saçtığı dumanlarla gözlerine perde çeken, firtınayla korkutup kaçırmaya çalışan Huvava, ağaçların bir ruhu olduğunu hatırlatarak onlara zarar verenlerin başına gelecekler konusunda insanları şöyle uyarır: "Anlamalıydılar/ buralardaki şeylere dokunulamaz./Bir şey yapmazlar da tekin değildirler/ Zamana verip başka zamanlara uçururlar lanetlerini” (Kutlu, 2009: 24) Huvava'da doğanın animistik gücünün görmezden gelinmesinin doğuracağı sonuçlara yer verilirken insana doğanın kutsal gücünden gelen dokunulmazlığı hatırlatılmaya çalışılır.

\section{3. İki Dostun Doğaya Düşman Olması: Yaban Hayatına Saldırı}

Huvava'nın "Yenilgi" adını taşıyan üçüncü bölümünde doğa koruyucusunun düşmanlarıyla karşı karşıya gelişi anlatılır. Bu bölümde sedir ağaçlarını kesmeyi bırakan Gılgamış ve Engidu aralarında anlaşarak Huvava'yı öldürmeye karar verirler. Büyük karşılaşmanın öncesinde doğada büyük bir sessizlik ve korku içinde bekleşen canlı ve cansız tüm varlıklar, saldırının şaşkınlığını atlatmaya çalışırken gözü dönmüş insanların doğadan ne istediğini anlamaya çalışmaktadır. Güçsüze yaşam hakkının tanınmadığı bu doğa katliamında düşmanlığın boyutu anlatılmaya çalış1ırken insandaki kontolsüz güce ve acımasız tavra vurgu yapılır:

“Ansızın öyle çok gürültü ve toz kötü söz doldu ki

\section{Dünyaya}

Yer titredi, gök sarsıldl

Bulutlar bile kaçtı

Zaman nereye saklanacağını bilemedi" (Kutlu, 2009: 25)

Ellerinde baltalar ve silahlarla büyük bir gürültü çıkararak gelen Gılgamış ve ordusu, ormanı yıkıp geçtikten sonra ardında derin bir sessizlik, nefret ve kötülük tohumları bırakır. Yazarın deyimiyle "yok ediciler" yani insanlar için asıl hedef, koruyucudur çünkü "önce kahramanlar ölmeli”dir (Kutlu, 2009: 28). Yorgun, güçsüz ve çaresiz olsa da sonuna kadar mücadeleden 
vazgeçmeyen Huvava, düşmanlarının karşısında dimdik durarak ölüme meydan okur; onu kahraman yapan da bu cesareti ve direnişidir. Yazar, düşmanları ile mücadele sırasında saldırganını öldürme firsatı ve gücü olan Huvava'ya herhangi bir eylemde bulundurmadığı gibi ona barış çağrısı yaptırır. $\mathrm{Bu}$ hareketin nedenini de "Ormanın dingin sonsuzluğuna ölümü ortak etmek olmazdı!/ Barış en kolayıdır..." (Kutlu, 2009: 31) dizeleriyle açıklar. Destanda cesur kimliği ile ön plana çıkarılan kahraman, yazarın da vurguladığı gibi aynı zamanda barışın sembolüdür. Bu çerçeveden bakıldığında savaş ve barış karşıtlığını ön plana çıkaran destanda ormanın; dinginlik ve birlikle özdeşleştirildiği ve barışın temsilcisi olarak okurun dikkatine sunulduğu görülür. Doğanın kendi içinde bir huzur, ahenk ve bütünlüğe sahip olduğu mesajı da destanın en başında "O büyük ağaçlar, dünya barışının ve birlikte yaşamının simgesi” (Kutlu, 2009: 14) sözleriyle açıkça verilir. Eserinde farklı kültürlerde de barış, sonsuzluk, hayat, süreklilik, şifa, doğum gibi özel anlamlar yüklenen ve tarihin her döneminde saygı duyulan ağacın önemine vurgu yapan yazar, okurunu ağacın hem hayatımızdaki yeri ve önemi hem de belleğimizdeki kültürel kodları üzerinde düşündürür.

Doğa/ insan, barış/ savaş ikilemleri üzerine kurgulanan destanda Gılgamış’tan sona bir diğer doğa düşmanı aynı zamanda Huvava'ya ölümü getiren erkin kanlı eli, Enkidu'dur. Gılgamış'la güçlerini birleştirerek aynı amaç için savaşmaya karar veren Enkidu, hükümdarın hem hizmetkârı hem de en yakın dostudur. Destanda görünümüyle insandan çok hayvanı andıran bu ilkel yaratık zalimliği ile de “Gılgamış’tan aşağı değildir:

“Gllgameş... Var oluşunun yok edici gücünü

Hakkı sanan yöneticilerin ilki

Yani; adı tarihi yazmış ilk zalim

Saldı bir köpek gibi emrine hazır Engidu'yu

Demir kollu, taş bacaklı, kurt boyunlu ilkel insanı

Toz koptu toprak delirdi, dünya bağırdı arada" (Kutlu, 2009: 31)

Yukarıda çizilen Enkidu portresi, ilk bakıştaki ilkel görüntüsüyle doğanın bir parçası izlenimi verir ve burada yabandan gelenin yabana olan düşmanlığı bir tezatlık gibi düşünülebilir. Yalnız destanda Enkidu'nun Gılgamış'la olan ilişkisine yakından bakıldığında Enkidu'nun Gılgamış'ın hizmetine girmesi ve onun sözünden çıkmaması, hâkimiyetin kaynağında da doğa düşmanlığının merkezinde de insanın olduğunun göstergesidir. Kurduğu kentin sınırlarını belirlemeye çalışan Gılgamış; ormanı krallığ 1 için bir tehlike, Huvava'yı da bir düşman olarak görmektedir. Yabani hayatı yok ederek kurduğu kentin sınırlarını genişletmeye çalışan Gılgamış, Huvava'yı yenerek doğadaki üstünlügünü kanıtlamak ününe ün katmak ister. Bu uğurda Enkidu’yu bir araç olarak kullanan Gılgamış'ın Huvava'yla savaşı, medeniyetin yabana karşı savaşıdır. "Gılgamış Destanına Ekoeleştirel Bakış" adlı makalede bu duruma açıklık getirilerek Gılgamış’ın doğaya savaş açma nedeni olarak teknolojik faaliyetler gösterilir: "Gılgamış'ın Humbava'yı öldürmesi ve sedir ormanlarını yok etmesi, onun politik ve askeri gücünün bir göstergesi olmasının yanında ülkesinin ileri medeniyet seviyesinin ve teknolojik üstünlügünün de bir kanıtı olacak ve son olarak da Gılgamış'ı halkını gözünde güçlü ve yenilmez bir kahraman ölümsüz bir lider kılacaktır” (Sarıkaya, 2012: 116). Medeniyet kurma arzusuyla kent ve yaban hayatını karşı karşıya getiren bu bakış, insanın doğayı kontrol altında tutma arzusuyla birleşerek tarihten günümüze çevresel sorunların nedeni olmuştur.

Gılgamış'ın Huvava'ya ile girdiği savaş, Enkidu'nun Huvava'yı öldürmesiyle sona erer; görünüşte insanoğlu doğaya üstün gelse de aslında savaşın kazanan bir tarafı yoktur. Yazarın da vurgulamak istediği gibi asıl yenilgi doğanın yararına olanı yitirmektir:

“Yerde cansız bir yığın olarak yatıyordu ölümlü: 
Gerçekte; tarih ĕgninde salliyordu onu

Bir gün çocuklar için uyanıncaya kadar...

Oydu; Huvava

Yenilmek buydu işte

Topluluğun yararına olan yitirmek,

Bir kişinin çirkin arzusunun sinırına bırakma herkesin olanı

Çıkarsızca savunan yok edilmesi" (Kutlu, 2009: 33)

Huvava'nın ölüm sahnesine geniş bir yer ayrılan eserde doğa kahramanın gerçekten ölmediği, tarihin koynunda geçici bir uykuya daldığı ve bir gün çocuklar için yeniden uyanacağı söylenir. Ölümü derin bir uykuya benzeten Kutlu, Huvava'yı tarihe gömmek yerine yaşaması için çocukların düşlerine, büyüklerin belleklerine emanet eder. Kitabının "Yeniden Doğuş" adını verdiği son bölümü de Huvava'yı ölümsüz kılmak için okura bir çağn niteliği taşır. Bu bölümde her sedir ağacının tohumundan itibaren Huvava'yı örnek aldığını, onu özleyerek büyüdüğünü ve onun kadar güçlü olmayı dilediğini belirten Kutlu, onun anısının tüm sedir ağaçlarında yaşadığının altını çizer. Burada dikkat çekici bir diğer nokta, sedir ağaçlarının ormanın kalbinde yaşayan Huvava'ya söylediği beş bin yıllık ninnidir. Eserini Huvava için kaleme aldığı bu ninniyle sona erdiren yazar, tüm insanlara doğayla barış çağrısında bulunarak doğanın sesini duyabilmeye davet eder:

"Hakll, binlerce yll yaşayabilir

Uzun bir uykuydu ölüm, uyandın

Hak gibi uyandin sen. Sedir gibi dik,

Sevecen yürek, korkusuz güç

Yeraltı alevinden doğan dăg

Sen Huvava, bağışla evlatlarını

Dünyanın açgözlü Gslgameşlerini

Tohumlar gibi sabırla beklendin

Yüreği ilk çarptıran can gibi hatta

Dönüşün yeni bir bahar olabilir

Ortak akıl, adanmış güç, büyük çaba

En sonunda dünya

Huvava ruhuyla sonsuza uzanabilir

Yaşayabilir

Ya-şa-ya-bi-lir" (Kutlu, 2009: 36).

Doğanın sesini duyabilen tüm kulaklara seslenen Huvava'nın hikâyesi, haklının yenilmezliğini, barışın tarafını, bağışlamanın yüceliğini, cesaretin gücünü ve sevginin büyüklüğünü anlatır. Bir başka deyişle doğanın gücünü ve mutlak galibiyetini simgeler. Bu ileti Ayla Kutlu'nun Huvava eserinden önce kaleme aldığı Kadın Destanı'nın satır aralarında da rastlanır: "Doğanın 
uygarliğa galip gelişinin en çarpıcı anlatımı Huvava'nrn ölümünden sonra bir çiğdem tarafindan yutulan Engidu'da resmedilir. Kendi bağrından kopan madeni paslandrrarak, mermeri aşındırarak toza dönüştüren doğa kendine ait olanr geriye almaktadır" (Gökçen, 2011: 287). Doğay1 savunmaktan öte sevmeyi ögreten Huvava, mücadelesiyle ilk çevre koruyucusu sıfatını ölümsüzlüğe taşırken hem çocuklar hem de büyükler için simgesel bir çevre kahramanına dönüşür. Yeniden Doğuş bölümünde ilk çevre koruyucusunun tarihin tozlu sayfalarından çıkarılarak onun mücadeleci ruhunun insanlığa örnek olması gerektiğini vurgulayan yazar, Huvava'nın ninnisini bir slogana dönüştürerek mesajını açık ve net bir şekilde verir. İnsanlık "ortak akı1, adanmış güç ve büyük çaba" ile hareket ederse doğayı koruyabilir ve Huvava'nın ruhunu yaşatabilir.

\section{Sonuç}

Bir ölümsüzlük arayışının hikâyesi olarak bilinen Gılgamış destanından uyarlanan Huvava, dünyayı ilgilendiren ortak bir sorundan ileri gelmektedir: İnsan ve doğa arasındaki üstünlük savaşı ve doğa tahribatı. Yazılış biçimleri ve dönemleri farklı olsa da her iki destan da vermek istedikleri mesaj itibariyle benzerlik gösterir. Her ikisi de orman katliamı, bitki ve hayvan türlerinin yok olması başta olmak üzere çevre sorunlarına dikkat çekmeye çalışarak okurda bir çevre bilinci oluşturmayı hedefler. Nitekim Huvava adlı destanın önsözünde yazar, "İnsanlı̆ga düşünce ve duygularımı armağan olarak sunmak istiyorum. (...) Yaşlarını göz ardı ederek bütün bilinçli insanlara sunduğum Huvava'nın hikâyesi, bir karşı destan olarak yazdiğım çağr metnidir. Yeryüzünün değerlerini aydınlatan ateş böcekleri gibi, genç kuşakların bellekleri de ışıldasın istiyorum" (Kutlu, 2009: 8) diye okura seslenir. Destan boyunca simgesel bir çevre kahramanı yaratmaya çalışan yazar, onun üzerinden vermeye çalıştı̆̆ mesajlarla okurda bir çevre bilinci oluşturmaya sanatın gücü ve estetik dili ile de kalıcı bir iz bırakmaya çalışır.

Eserinde çevresel sorunlarının altında insan merkezci bakışın yattı̆̆ı mesajını veren Kutlu, bu bakış açısının verdiği zararları göstermeye çalışırken okuru insanın çevreye karşı temel sorumlulukları üzerine düşündürmüsstür. İnsanı doğanın efendisi olarak gören, doğayı bütünüyle insanın hâkimiyetine sokmaya çalışan bu zihniyetin sadece günümüzün sorunu olmadığına dikkat çekmiş ve binlerce yıl öncede tablonun şimdikinden farklı olmadığının altını çizmiştir Huvava'da insanın doğa karşısındaki tavrının yanlışlığını vurgulamaya çalışan Kutlu, derin ekolojinin temel hedeflerinden biri olan insan merkezci algıyı yıkarak yerine doğa merkezci (eco-centric) bir bakış açısını getirmeyi hedeflemiştir. Doğa-merkezci etik anlayışında derin ekoloji felsefesinin temelini oluşturan içsel değer (inherent value), biyosferik zenginlik ve çeşitlilik kavramlarının yansımalarını görmek mümkündür. Ekosistem içinde her bir varlığın kendi içinde özel ve değerli olduğu mesaj1 verilen destanda doğanın animistik gücünün görmezden gelinmesi ve doğanın medeniyet kurma arzusuyla tahrip edilmesi eleştirilmiştir. Esere ekolojik duyarlılıkla yaklaşıldığında Gılgamış'tan uyarlanan destanının yaban hayatını tehdit olarak göstermesi, doğanın korumaya ihtiyaç duyması, ve insanı ilk kez doğadan ayrı görme zihniyeti gibi pek çok ekolojik meselenin sorgulandığı görülür.

Huvava'nın hikâyesiyle doğanın sesini duyabilen tüm kulaklara seslenen yazar, haklının yenilmezliğini, barışın tarafını, bağışlamanın yüceliğini, cesaretin gücünü ve sevginin büyüklüğünü anlatır. Doğayı savunmaktan öte sevmeyi öğreten Huvava, mücadelesiyle ilk çevre koruyucusu sıfatını ölümsüzlüğe taşırken hem çocuklar hem de büyükler için simgesel bir çevre kahramanına dönüşür. İlk çevre koruyucusunun tarihin tozlu sayfalarından çıkarılarak onun mücadeleci ruhunun insanllğa örnek olması gerektiğini vurgulayan yazar, eserinin önsözünde "yeryüzünün elimizden gitmekte olduğu bu günlerde şimdiye kadar bir simgesi bulunmayan koruma eylemleri ve planlar dizgesinin sembolü olarak onun adını ve hayali kimliğini bütün dünyaya öner"(Kutlu, 2009:7)ir. 


\section{Kaynakça}

Avuklu, M. (2013). Sabahattin Ali'nin bir orman hikâyesi adlı hikâyesine ekoeleştirel bir bakış. Atatürk Üniversitesi Sosyal Bilimler Enstitüsü Dergisi, 51, 203-210.

Alpaslan-Gökalp, G. G. (2007). Metinlerarası ilişkiler ve Gılgamış destanının çağdaş yorumları. Multilingual Yayınları.

Aylanç, M. (2018). Fikret Demirağ'ın şiirlerine ekoeleştirel bakış. Folklor/ Edebiyat, 24 (96), 37-52. https://doi.org/10.22559/folklor.409

Aslan, C. (2017). Memet Baydur'un Tensing adlı tiyatro oyununa ekoeleştirel bir yaklaşım. Akademik Sosyal Araştırmalar Dergisi, 5(61), 102-111.

Balık, M. (2013). Çevreci Eleştiri ışı̆̆ında Latife Tekin'in romanları. Çevrimiçi Tematik Türkoloji Dergisi, V(1), 1-16.

Balık, M., \& Tekben, B. (2014). Çevreci eleştiri kuramı açısından Müge İplikçi'nin Cemre adlı roman1. Akademik Sosyal Araştırmalar Dergisi, 2(2/1), 338-351.

Budan, C. Y. (2017). Çevreci eleştiri bağlamında Yaşar Kemal'in Kuşlar da Gitti romanı üzerine bir değerlendirme. Bartın Üniversitesi Edebiyat Fakültesi Dergisi, 2(1), 3-20.

Cengiz, Arlı, Ç. (2014). Buket Uzuner'in Uyumsuz Defne Kaman'ın Maceraları Su romanına ekoeleştiri ve ekofeminizm penceresinden bakış. Frankofoni, 26, 1-11.

Ergin, M., \& Dolcerocca, Ö. N. (2016). Edebiyata ekoeleştirel yaklaşımlar: ekoşiir ve Elif Sofya. Sefad, 36, 297-314. https://doi.org/10.21497/sefad.285241

Gökçen, N. (2011). Kadın destanı: kadın-doğadan erkek-uygarlığa bir başkaldırı anlatısı. Kadın Yazarlar Sempozyumu Bildiriler Kitabı: Ayla Kutlu Edebiyatı (1. basım, ss. 275-287). Bilgi Yayıncilik.

Gül, F. (2013). İnsan-doğa ilişkisi bağlamında çevre sorunları ve felsefe. Pamukkale Üniversitesi Sosyal Bilimler Enstitüsü Dergisi, 14, 17-20.

Güller, K. (1995). Şamanizm ve Animizm'in Anadolu Türk Kültürüne yaptığı bazı etkiler üzerine düşünceler. Öneri Dergisi, 1(2), 159-162. https://doi.org/10.14783/maruoneri.708116

Kabak, T. (2018). Dadaloğlu'nun şiirlerine ekoeleştirel bir yaklaşım. Motif Akademi Halkbilimi Dergisi, 11(21), 36-47.

Kutlu, A. (2009). Huvava, Bilgi Yayınevi.

Mutlu, B., \& Başoğlu, N. (2012). Ekoeleştiri kuramına göre Aytül Akal'ın Ağaç Masalları'nda insandoğa ilişkisi - V. Ulusal Çocuk ve Gençlik Edebiyatı Yaşayan Yazarlar Sempozyum Dizisi Çocuk ve Gençlik Edebiyatında Aytül Akal Sempozyumu.

Öztürk, O. (2020, Şubat, 20). Huvava. Mitoloji Sözlüğü. http://ozhanozturk.com/2017/11/01/mezopotamya-mitolojisi-sozlugu-g-z/

Oppermann, S. (2012). Ekoeleştiri: çevre ve edebiyat çalışmalarının dünü ve bugünü. S. Oppermann (Eds.), Ekoeleştiri Çevre ve Edebiyat, (1. basım, ss. 9-58.). Phoenix Yayınları.

Sarıkaya, B. D. (2012). Gılgamış Destanı'na ekoeleştirel bir bakış. S. Oppermann (Eds.), Ekoeleştiri Çevre ve Edebiyat, (1. basım, ss. 93-128). Phoenix Yayınları.

Sazyek H., \& Sürücü Y. (2018). Cahit Külebi'nin şiirlerine ekoeleştiri çerçevesinden bakmak. KOSBED, 36, 25-38. 
Solak, C. (2012). Bir ekoeleştiri denemesi: Behiç Ak'ın Tek Kişilik Şehir oyununda birey, toplum ve çevre ilişkileri. A Ü. Türkiyat Araştırmaları Enstitüsü Dergisi (TAED), 47, 211-224.

Sümer, S. Z. (2016). Bozkırdan Hikâyeler: Filiz Kılıçel'in öykülerinde çevreci eleştiri bağlamında doğa edebiyatını yeniden keşfetmek. Uluslararası Sempozyum: Geçmişten Günümüze Bozkır, 8, 741-750.

Uzundemir, Ö. (2005). Ayla Kutlu's Kadın Destanı and the modification of the epic. Ankara Üniversitesi Fen-Edebiyat Fakültesi Journal of Arts and Sciences, 1(3), 119-126.

Yalçın Çelik, S. D. (2016). Aytül Akal'ın Orman Masalları kitap dizisi örnekleminde çocuklara çevreci bakış açısının verilmesi, Qafqaz Üniversitesi Uluslararası Çocuk Edebiyatı Seтровуити III. 